ISSN 1392-3196 / e-ISSN 2335-8947

Zemdirbyste-Agriculture, vol. 107, No. 3 (2020), p. 227-234

DOI 10.13080/z-a.2020.107.029

\title{
Permanent grassland hay-derived biochar increases plant N, P and $K$ uptake on an acidic soil
}

\author{
Henn RAAVE ${ }^{1}$, Jordi ESCUER-GATIUS ${ }^{2}$, Karin KAUER ${ }^{2}$, Merrit SHANSKIY ${ }^{2}$, \\ Tõnu TÕNUTARE², Alar ASTOVER ${ }^{2}$ \\ ${ }^{1}$ Estonian University of Life Sciences, Chair of Crop Science and Plant Biology \\ Kreutzwaldi 1 Tartu 51006, Estonia \\ E-mail: henn.raave@emu.ee \\ ${ }^{2}$ Estonian University of Life Sciences, Chair of Soil Science \\ Kreutzwaldi 1 Tartu 51006, Estonia
}

\begin{abstract}
The importance of permanent grasslands in the feed production has decreased in Estonia in the last decades, because of the low feeding value of the biomass. Therefore, there is a need for new solutions for utilization of this biomass. One way of giving value to this resource would be its application in the production of biochar (BC) and its subsequent use for increasing the carbon $(\mathrm{C})$ and nutrient concentration of previously low-fertility soils. This study examined (i) the properties of biochar produced from permanent grassland hay at three $\left(300^{\circ} \mathrm{C}, 550^{\circ} \mathrm{C}\right.$ and $850^{\circ} \mathrm{C}$ ) pyrolysis temperatures and (ii) the impact of biochar on the uptake of $\mathrm{N}, \mathrm{P}, \mathrm{K}, \mathrm{Ca}$ and $\mathrm{Mg}$ and the biomass yield of perennial ryegrass (Lolium perenne L.) on a strongly acidic (pH 4.2) soil.

It was found that the permanent grassland hay dominated by reed canary grass (Phalaris arundinacea L.) is a suitable raw material for biochar production. This biochar is a potassium (K) rich fast-acting liming agent, which also contains a remarkable amount of $\mathrm{N}$. The addition of this biochar into acidic soil reduces soil acidity and significantly increases plant uptake of $\mathrm{N}, \mathrm{P}$ and $\mathrm{K}$, which has a short term positive impact on biomass yield. The increase of pyrolysis temperature changes biochar properties like neutralization capacity, acidity $(\mathrm{pH})$, nutrient concentration and the release of nutrients from biochar, but these changes do not have a significant impact on the effect the biochar has on plant nutrition and yield. The only exception was phosphorus (P) uptake, which was the highest when the biochar was produced at $550^{\circ} \mathrm{C}$ temperature.
\end{abstract}

Key words: biochar properties, biomass yield, nutrient release from biochar, nutrient uptake, pyrolysis temperature.

\section{Introduction}

In Estonia, there are many high-yielding permanent types of grassland, which are cut once a year to avoid secondary forest growth. Today the harvested biomass is mostly left to decay at the edge of the grassland because of its low feeding value. It has been found that it could be used as a fuel in heating plants, but because of high concentration of ash and alkali metals and low energy density it is not economically viable (Heinsoo et al., 2010; Kukk et al., 2010). One way of giving value to this resource would be its application in the production of biochar, which could be used for improving the soil fertility.

Biochar is a solid material obtained from thermochemical conversion of biomass in an oxygenlimited environment during pyrolysis and gasification process (Lehmann, Joseph, 2015). Both these processes are exothermic and are used for producing energy from biomass. When incorporated into the soil, biochar impacts soil properties including the soil $\mathrm{C}$ concentration (Sohi, 2012), specific surface area and porosity (Baiamonte et al., 2015; Nelissen et al., 2015), field water-holding capacity (Basso et al., 2013; Ma et al., 2016), cationexchange capacity and acidity (Laghari et al., 2016), which could have a positive effect on plant growth (Ding et al., 2016). Due to the high concentration of stabile carbon (C) compounds, the biochar decomposes very slowly in the soil that enables the long-term removal of $\mathrm{C}$ from the nutrient cycles, thereby being beneficial for climate change mitigation (Sohi, 2012). Also it has been found that biochar inhibits the release of greenhouse gases from the soil, but it has not been confirmed by all studies (Cayuela et al., 2014; Feng, Zhu, 2017; Buchkina et al., 2019; Escuer-Gatius et al., 2020).

Biochar can also be applied to act as an organic fertilizer that enriches the soil on a short-term basis with essential plant nutrients (Gaskin et al., 2010; Kloss et al., 2014). Nutrient amounts and their availability for plants in the biochar depends on its raw material (Enders et al., 2012; Rajkovich et al., 2012) and pyrolysis temperature (Gaskin et al., 2010; Kloss et al., 2012; Ippolito et al., 2015).

Please use the following format when citing the article:

Raave H., Escuer-Gatius J., Kauer K., Shanskiy M., Tõnutare T., Astover A. 2020. Permanent grassland hay-derived biochar increases plant N, P and K uptake on an acidic soil. Zemdirbyste-Agriculture, 107 (3): 227-234. DOI 10.13080/z-a.2020.107.029 
Although the properties of biochar produced from various raw materials have been studied intensively, the application of graminaceous plants in temperate climate regions as a possible raw material for biochar production has received less attention. The majority of studies have been focused on the properties and impacts of biochar produced from graminaceous plants such as Miscanthus spp. and switchgrass (Panicum virgatum L.) growing in warm climate regions (Mimmo et al., 2014; Ding et al., 2016). Properties and impact of biochar produced from the biomass of temperate climate plants may be different, as was shown by Van de Voorde et al. (2014), who concluded that the species of the raw material plants has a significant impact on the properties of biochar and the effect it has on the crops.

To date, it remains unclear whether biochar effect on plant nutrition depends on the pyrolysis temperature, at which it was produced. There have been few experiments studying the effect of biochars produced from the same raw material at different temperatures on nutrient uptake and soil (Rajkovich et al., 2012; Zheng et al., 2013; Nelissen et al., 2014). In most cases, the effect of pyrolysis temperature on nutrient release from biochar has been evaluated analytically (Enders et al., 2012; Wang et al., 2012; Mukherjee, Zimmerman, 2013).

The purpose of this research was to examine (i) the properties of biochar produced from permanent grassland hay at three $\left(300^{\circ} \mathrm{C}, 550^{\circ} \mathrm{C}\right.$ and $\left.850^{\circ} \mathrm{C}\right)$ pyrolysis temperatures and (ii) the impact of biochar on the uptake of $\mathrm{N}, \mathrm{P}, \mathrm{K}, \mathrm{Ca}$ and $\mathrm{Mg}$ and perennial ryegrass (Lolium perenne L.) yield on a strongly acidic ( $\mathrm{pH} 4.2)$ soil.

We hypothesized that permanent grassland hay is a suitable raw material for biochar production, whose fertilizing properties are significantly influenced by the pyrolysis temperature.

\section{Materials and methods}

The biochar $(B C)$ and soil. The $\mathrm{BC}$ was produced from permanent grassland hay dominated by reed canary grass (Phalaris arundinacea L.), which is very common high yielding species on wet permanent grasslands in Estonia. The grass was cut at the seedripening phase. The ash concentration of harvested hay biomass was $9.12 \%$, and the total (tot) concentration of nitrogen $(\mathrm{N})$, phosphorus $(\mathrm{P})$, potassium $(\mathrm{K})$, calcium (Ca) and magnesium $(\mathrm{Mg})$ (hereafter $\mathrm{N}_{\text {tot }}, \mathrm{P}_{\text {tot }}, \mathrm{K}_{\text {tot }}, \mathrm{Ca}_{\text {to }}$ and $\mathrm{Mg}_{\text {tot }}$, respectively) was $2.3,0.25,2.22,0.92$ and $0.46 \%$, respectively. The hay was pressed into pellets at Ecopellet Ltd. (Estonia) and torrefied at a temperature of $300^{\circ} \mathrm{C}$ in the Fraunhofer Institute (Germany). From there, the torrefied biochar (hereafter $\mathrm{BC}_{300}$ ) pellets were taken to the Lithuanian Energy Institute, where they were pyrolysed at $550^{\circ} \mathrm{C}$ (hereafter $\mathrm{BC}_{550}$ ) or $850^{\circ} \mathrm{C}$ (hereafter $\mathrm{BC}_{850}$ ) temperatures. The average length of biochar pellets was $10-20 \mathrm{~mm}$, the diameter $7 \mathrm{~mm}$.

The plant growth substrate was the upper $20 \mathrm{~cm}$ of eroded Dystric Endostagnic Glossic Retisol (Colluvic) (WRB, 2014) excavated from permanent grassland. The soil texture was sandy loam (73\% sand, $22 \%$ silt and $5 \%$ clay). Before the experiment, soil was dried and sieved through a $1-\mathrm{cm}$ sieve for removal of stones and plant roots. The soil $\mathrm{N}_{\text {tot }}, \mathrm{C}_{\text {tot }}, \mathrm{P}_{\text {tot }}, \mathrm{K}_{\text {tot }}, \mathrm{Ca}_{\text {tot }}$ and $\mathrm{Mg}_{\text {to }}$ concentrations were $0.07,12.4,0.214,0.715,0.538$ and $1.48 \mathrm{~g} \mathrm{~kg}^{-1}$, respectively. Plant-available $\mathrm{P}, \mathrm{K}, \mathrm{Ca}$ and $\mathrm{Mg}$ concentrations of the soil determined by ammonium lactate (AL) method (Egner et al., 1960) (hereafter $\mathrm{P}_{\mathrm{AL}}$, $\mathrm{K}_{\mathrm{AL}}, \mathrm{Ca}_{\mathrm{AL}}$ and $\mathrm{Mg}_{\mathrm{AL}}$, respectively) were $0.02,0.07,0.475$ and $0.155 \mathrm{~g} \mathrm{~kg}^{-1}$, respectively.
Experimental design. The pot experiment was conducted under controlled growing chamber conditions over 60 days at the Estonian University of Life Sciences in 2017. The experimental factors were (i) the presence or absence of biochar and (ii) biochar pyrolysis temperatures $\left(300^{\circ} \mathrm{C}, 550^{\circ} \mathrm{C}\right.$ and $\left.850^{\circ} \mathrm{C}\right)$. The experiment also included a control treatment, in which unamended soil was used. The total number of treatments in the experiment was 4, all with four replications.

PVC tubes (Wavin, The Netherlands) with a length of $30 \mathrm{~cm}$, diameter of $10.5 \mathrm{~cm}$ and surface area of $0.0095 \mathrm{~m}^{-2}$ were used as growing pots in the experiment. The tubes were sealed at the bottom with a 3 -cm-thick styrofoam cap with a hole in the centre for free water drainage. The total soil volume in one pot was $2.4 \mathrm{~L}$ and the soil density in the pot $1.3 \mathrm{~g} \mathrm{~cm}^{-3}$. The pots were filled with soil in two parts, the lower 10-27 cm layer and then the upper $0-10 \mathrm{~cm}$ layer. Prior to the addition of the upper soil layer, biochar pellets $\left(8.7 \mathrm{~g}\right.$ per pot, $\left.915.8 \mathrm{~g} \mathrm{~m}^{-2}\right)$ were mixed into the added soil.

After filling the pots, tap water was added to the soil until field capacity was reached (volumes of applied and drained water were equal) and then perennial ryegrass (Lolium perenne L.) cultivar 'Jubilee EG' 100 seeds were sown into each pot. During the experiment, growth room air temperature was maintained at $17^{\circ} \mathrm{C}$, and the relative air humidity at $60 \%$. The light mode during the entire experiment was $13 / 11 \mathrm{~h}$ light/darkness. During the first 30 days of the growing period, the plants were irrigated manually three times a week at a rate of $125 \mathrm{ml}$ per pot. This was increased to $150 \mathrm{ml}$ per pot in the second growing period. In both growing periods, the irrigation rate was increased by $25 \mathrm{ml}$ one week before harvest. The water amount was adjusted according to plant biomass size to avoid leaching.

Data analysis. Soil agrochemical parameters were determined at the beginning and at the end of the experiment. At the beginning of the experiment, a single average soil sample was taken before the soil was put into the pots. At the end of the experiment, a sample was taken from the upper $(0-10 \mathrm{~cm})$ and lower $(10-27 \mathrm{~cm})$ soil layers of all pots. The following parameters were determined in the soil sample taken at the beginning and the end of the experiment from the $0-10 \mathrm{~cm}$ soil layer: soil acidity with a $\mathrm{pH}$ meter SevenCompact (Mettler Toledo Inc., Canada), soil ratio to $\mathrm{KCl}$ solution 1:2.5 and the $\mathrm{N}_{\text {toto }}, \mathrm{C}_{\text {tot, }} \mathrm{P}_{\text {tot }} \mathrm{Ca}_{\text {tot }} \mathrm{Mg}_{\text {tot, }} \mathrm{P}_{\mathrm{AL}}, \mathrm{K}_{\mathrm{AL}} \mathrm{Ca}_{\mathrm{AL}}$ and $\mathrm{Mg}_{\mathrm{AL}}$ concentrations. To clarify the extent to which $\mathrm{N}$ mobility was affected by the applied biochar, the $\mathrm{N}_{\text {tot }}$ concentration was also determined in the $10-27 \mathrm{~cm}$ soil layer.

For the determination of $\mathrm{P}_{\text {tot }}, \mathrm{K}_{\text {tot }}, \mathrm{Ca}_{\text {tot }}$ and $\mathrm{Mg}_{\text {tot }}$, the soil sample was at first dried, then ground and mineralized with $2.5 \mathrm{ml} \mathrm{HNO}_{3}$ and $7.5 \mathrm{ml} \mathrm{HCl}$ in a microwave oven (microwave digestion method, https:// www.berghof-instruments.com/en/product/speedwaveentry/).

The chemical properties of the ground biochar were analysed twice, at the beginning and at the end of the experiment. In the first analysis, $\mathrm{pH}, \mathrm{N}_{\text {tot }}, \mathrm{NO}_{3}-\mathrm{N}, \mathrm{NH}_{4}-\mathrm{N}$, $\mathrm{C}_{\text {tot }}, \mathrm{P}_{\text {tot }}, \mathrm{K}_{\text {tot }}, \mathrm{Ca}_{\text {tot }}, \mathrm{Mg}_{\text {tot }}, \mathrm{P}_{\mathrm{AL}}, \mathrm{K}_{\mathrm{AL}}, \mathrm{Ca}_{\mathrm{AL}}, \mathrm{Mg}_{\mathrm{AL}}$, waterextractable $\mathrm{N}$, ash and biochar acid-neutralising capacity were determined. The $\mathrm{pH}$ of the biochar and total nutrient concentrations were determined with similar methods to those for soil.

The water-extractable $\mathrm{N}$ was analysed separately in the whole and ground pellets granules by shaking them in water for $1 \mathrm{~h}$. The $\mathrm{N}_{\text {tot }}$ concentration 
was determined by Dumas dry combustion method with the CNS elemental analyser (Elementar). The nitrate nitrogen $\left(\mathrm{NO}_{3}-\mathrm{N}\right)$ and ammonium nitrogen $\left(\mathrm{NH}_{4}-\mathrm{N}\right)$ were analysed by using flow injection analyses by Tecator ASN 65-32/84 (FOSS, Sweden) (Ruzicka, Hansen, 1988). The biochar acid-neutralising capacity was analysed by using $1 \mathrm{M} \mathrm{HCl}$ solution according to standard EVS-EN 12945:2014+A1:2016 (Liming materials - Determination of neutralizing value - Titrimetric methods) and ash concentration by heating biochar samples for $6 \mathrm{~h}$ at $750^{\circ} \mathrm{C}$ temperature in a muffle furnace.

At the end of the experiment, biochar pellets were sieved out from the soil and analysed for $\mathrm{N}_{\text {tot }}, \mathrm{C}_{\text {tot }}$, $\mathrm{P}_{\text {tot }}, \mathrm{K}_{\text {tot }}, \mathrm{Ca}_{\text {tot }}$ and $\mathrm{Mg}_{\text {tot }}$ concentration similarly to the samples at the beginning of the experiment to determine the loss of those nutrients from biochar.

The biochar cumulative pore volume was determined according to Density Functional Theory (DFT) method (Lastoskie et al., 1993) and the specific area by Brunauer-Emmett-Teller (BET) method (Brunauer et al., 1938).

The aboveground biomass yield was determined twice during the experiment, both times after a 30-day growing period. Plants were cut $2 \mathrm{~cm}$ above the soil. Root yield was determined at the end of the experiment. Roots were removed from the soil by sieving with a $2-\mathrm{cm}$ sieve. The raw material was weighed, air-dried at $105^{\circ} \mathrm{C}$ temperature and weighed again. Based on the weight difference, the dry matter (DM) concentration (\%) in biomass was calculated. The biomass DM yield (DMY) was calculated based on DM concentration and fresh biomass yield. From dry biomass that was first ground and then ashed in sulphuric acid (AOAC, 1990), the P, K, $\mathrm{Ca}$ and $\mathrm{Mg}$ were determined with a micro-plasma atomic emission spectrometer (Agilent). The $\mathrm{N}_{\text {tot }}$ concentration was determined by the Dumas dry combustion method with the CNS elemental analyser (Elementar). The nutrient concentration (\%) in hay (raw material for the biochar) was analysed similarly to aboveground biomass harvested from pots.
Calculations. Nutrient uptake (NUP) $\left(\mathrm{g} \mathrm{m}^{-2}\right)$ was determined as follows:

$$
\mathrm{NUP}=\mathrm{DMY} \times \mathrm{N}_{\mathrm{C}} / 100,
$$

where DMY is biomass dry matter yield $\left(\mathrm{g} \mathrm{m}^{-2}\right)$, $\mathrm{N}_{\mathrm{C}}$ - nutrient concentration in dry biomass (\%).

Total nutrient uptake $\left(\mathrm{NUP}_{\text {tot }}\right)\left(\mathrm{g} \mathrm{m}^{-2}\right)$ per whole experimental period was calculated as follows:

$$
\mathrm{NUP}_{\text {total }}=\mathrm{NUP}_{\mathrm{AGB} 1}+\mathrm{NUP}_{\mathrm{AGB} 2}+\mathrm{NUP}_{\mathrm{R}} \text {, }
$$

where NUP ${ }_{\mathrm{AGB}}$ is nutrient uptake by aboveground biomass $\left(\mathrm{g} \mathrm{m}^{-2}\right), \mathrm{NUP}_{\mathrm{R}}-$ nutrient uptake by roots $\left(\mathrm{g} \mathrm{m}^{-2}\right)$; indexes 1 and 2 indicate the $1^{\text {st }}$ and $2^{\text {nd }}$ cuts, respectively.

Statistical analysis. One-way analysis of variance (ANOVA) was used for the assessment of the influence of biochar incorporation on soil $\mathrm{pH}$, plant-available and total nutrient concentrations and on cumulative nutrient uptake by plants. The significance of differences between treatment means (control, $\mathrm{BC}_{300}, \mathrm{BC}_{550}$ and $\mathrm{BC}_{850}$ ) was assessed by Tukey's post hoc test at level $p<0.05$. The relationships between nutrient uptake from soil with soil agrochemical parameters were tested with Pearson correlation analysis. Statistical analysis was conducted by the software Statistica, version 13 (StatSoft Inc., USA).

\section{Results and discussion}

Properties of hay biochar (BC). Biochar properties were significantly $(p<0.01)$ influenced by the pyrolysis temperature. The rise in pyrolysis temperature increased biochar ash concentration, acid-neutralization capacity and acidity (Table 1) supporting findings of previous studies for biochar produced from wood, maize, manure, paper waste and hazelnut (Enders et al., 2012; Rajkovich et al., 2012; Zeng et al., 2013).

In $\mathrm{BC}_{300}, \mathrm{P}_{\text {tot, }} \mathrm{K}_{\text {tot, }} \mathrm{Ca}_{\text {tot }}$ and $\mathrm{Mg}_{\text {tot }}$ concentrations were similar to those in the raw material, but in $\mathrm{BC}_{550}$ and $\mathrm{BC}_{850}$, they were more than twice as high as those in $\mathrm{BC}_{300}$ (Table 2). This was due to greater loss of volatile compounds at the higher pyrolysis temperatures (Novak et al., 2009; Zheng et al., 2013).

Table 1. Selected physical and chemical properties of the hay biochar (BC) produced at different pyrolysis temperatures

\begin{tabular}{ccccccc}
\hline Treatment & $\begin{array}{c}\text { Acidity } \\
(\mathrm{pH})\end{array}$ & $\begin{array}{c}\text { Ash } \\
\%\end{array}$ & $\begin{array}{c}\text { Acid neutralization } \\
\text { capacity, } \\
\mathrm{CaCO} \\
\%\end{array}$ & $\begin{array}{c}\text { Surface } \\
\text { area } \\
\mathrm{m}^{2} \mathrm{~g}^{-1} \\
(\mathrm{BET})\end{array}$ & $\begin{array}{c}\text { Cumulative } \\
\text { pore volume } \\
\mathrm{cm}^{3} \mathrm{~g}^{-1} \\
(\mathrm{DFT})\end{array}$ & $\begin{array}{c}\text { Concentration of } \\
\text { volatile compounds } \\
\%\end{array}$ \\
\hline $\mathrm{BC}_{300}$ & 6.8 & 10.4 & 4.35 & 0.99 & 0.0015 & 62.9 \\
$\mathrm{BC}_{550}$ & 10.1 & 20.3 & 8.15 & 3.91 & 0.018 & 16.1 \\
$\mathrm{BC}_{850}$ & 11.8 & 23.0 & 8.11 & 6.17 & 0.008 & 9.5 \\
\hline
\end{tabular}

Note. The index indicates the temperature $\left(300^{\circ} \mathrm{C}, 550^{\circ} \mathrm{C}\right.$ or $\left.850^{\circ} \mathrm{C}\right)$, at which the biochar was produced; BET - Brunauer-EmmettTeller method; DFT - Density Functional Theory method.

Table 2. Nutrient concentration (\% in dry matter) in biochar (BC)

\begin{tabular}{ccccccc}
\hline Treatment & $\mathrm{N}_{\text {tot }}$ & $\mathrm{C}_{\text {tot }}$ & $\mathrm{P}_{\text {tot }}$ & $\mathrm{K}_{\text {tot }}$ & $\mathrm{Ca}_{\text {tot }}$ & $\mathrm{Mg}_{\text {tot }}$ \\
\hline \multicolumn{7}{c}{ At the beginning of the experiment } \\
\hline $\mathrm{BC}_{300}$ & $2.82 \pm 0.01$ & $53.5 \pm 0.03$ & $0.24 \pm 0.01$ & $2.28 \pm 0.03$ & $0.93 \pm 0.03$ & $0.47 \pm 0.04$ \\
$\mathrm{BC}_{550}$ & $2.92 \pm 0.01$ & $65.9 \pm 0.01$ & $0.54 \pm 0.01$ & $4.62 \pm 0.11$ & $2.11 \pm 0.01$ & $0.93 \pm 0.04$ \\
$\mathrm{BC}_{850}$ & $2.56 \pm 0.01$ & $68.1 \pm 0.32$ & $0.60 \pm 0.02$ & $5.10 \pm 0.24$ & $2.44 \pm 0.04$ & $1.03 \pm 0.04$ \\
\hline \multicolumn{7}{c}{ At the end of the experiment } \\
\hline $\mathrm{BC}_{300}$ & $1.76 \pm 0.08$ & $35.9 \pm 1.07$ & $0.09 \pm 0.01$ & $0.06 \pm 0.01$ & $0.74 \pm 0.01$ & $0.23 \pm 0.01$ \\
$\mathrm{BC}_{550}$ & $1.32 \pm 0.04$ & $33.3 \pm 0.71$ & $0.46 \pm 0.02$ & $0.46 \pm 0.01$ & $1.41 \pm 0.11$ & $0.79 \pm 0.03$ \\
$\mathrm{BC}_{850}$ & $0.79 \pm 0.04$ & $28.9 \pm 1.07$ & $0.48 \pm 0.01$ & $0.93 \pm 0.04$ & $1.64 \pm 0.08$ & $0.80 \pm 0.01$ \\
\hline
\end{tabular}

Note. The index indicates the temperature $\left(300^{\circ} \mathrm{C}, 550^{\circ} \mathrm{C}\right.$ or $\left.850^{\circ} \mathrm{C}\right)$, at which the biochar was produced; the values are presented as mean \pm standard error $(n=4)$. 
$\mathrm{N}_{\text {tot }}$ concentration was high in all three biochars. This high $\mathrm{N}_{\text {tot }}$ amount has been noted earlier for lucerne (Medicago sativa L.) (3.1\%) and switchgrass (Panicum virgatum L.) (2.3\%) biochar (Wang et al., 2015) and tomato (Solanum lycopersicum L.) (2.6\%) aboveground biomass biochar (Smider, Singh, 2014); however, there are also many studies, which suggest that the $\mathrm{N}_{\text {tot }}$ concentration may be two times lower in herbaceous biomass biochars (Ippolito et al., 2015).

$\mathrm{N}_{\text {tot }}$ concentration in biochar was affected by pyrolysis temperature, but its impact on $\mathrm{N}_{\text {tot }}$ amount was in the current study less than it was showed previously. Wang et al. (2015) found that an increase in pyrolysis temperature from $300^{\circ} \mathrm{C}$ to $600^{\circ} \mathrm{C}$ reduced $\mathrm{N}_{\text {tot }}$ concentration of biochar produced from lucerne and switchgrass by $28 \%$ and $52 \%$, respectively. In the current study similarly to Wang et al. (2015), the lowest $\mathrm{N}_{\text {tot }}$ was in the $\mathrm{BC}_{850}$ that was produced at the highest temperature, but its difference from $\mathrm{BC}_{300}$ was only $10 \%$. The reason for the $\mathrm{N}$ concentration being so high in $\mathrm{BC}_{850}$ was probably the short duration of pyrolysis process $(1 \mathrm{~h}$ at $850^{\circ} \mathrm{C}$ ).

Release of nutrients from biochar in soil. During the two-month experiment, nutrient concentration in biochar were decreased significantly in the soil (Table 2). The most decreased elements were $\mathrm{K}$ and $\mathrm{N}$, and less changed concentration was of $\mathrm{P}, \mathrm{Ca}$ and $\mathrm{Mg}$. The greatest $\mathrm{N}_{\text {tot }}$ reduction occurred in $\mathrm{BC}_{550}$ and $\mathrm{BC}_{850}$, which was unexpected, as most of the studies to date have shown that the amount of extractable $\mathrm{N}$ in biochar decreases with increasing pyrolysis temperature (Wang et al., 2012; Mukherjee, Zimmerman, 2013; Naeem et al., 2014).

Analysis of water-extractable $\mathrm{N}$ of whole and ground biochar pellets showed that slightly more $\mathrm{N}$ was extracted from ground $\mathrm{BC}_{300}-0.89$ and $1.33 \mathrm{mg} \mathrm{g}^{-1}$, respectively $(n=4)$. However, the water-extractable $\mathrm{N}$ for whole and ground biochar was similar in $\mathrm{BC}_{850}-0.11$ and $0.08 \mathrm{mg} \mathrm{g}^{-1}$, respectively $(\mathrm{n}=4)$ and $\mathrm{BC}_{550}-0.04$ and $0.05 \mathrm{mg} \mathrm{g}^{-1}$, respectively $(\mathrm{n}=4)$. This result suggests that in $\mathrm{BC}_{300}, \mathrm{~N}$ compounds were dispersed throughout the granule, whereas in $\mathrm{BC}_{550}$ and $\mathrm{BC}_{850}$ they were more often located in the surface layer.
Nitrogen emissions from biochar intensify when pyrolysis temperature rises above $400^{\circ} \mathrm{C}$ (Zheng et al., 2013). It is probable that evaporated $\mathrm{N}$ that did not escape the granule during the pyrolysis condensed in the top layer of the $\mathrm{BC}_{550}$ and $\mathrm{BC}_{850}$ pellets. The biochar pellets retained their shape in soil; therefore, the release of $\mathrm{N}$ was possible only from the pellets surface layer. This was probably the reason, why greater reduction of $\mathrm{N}_{\text {tot }}$ occurred in $\mathrm{BC}_{550}$ and $\mathrm{BC}_{850}$.

On the other hand, it is notable that the waterextractable $\mathrm{N}$ concentration in the surface layer of $\mathrm{BC}_{300}$ was 8-20 times higher than that of $\mathrm{BC}_{550}$ and $\mathrm{BC}_{850}$, but the amount of $\mathrm{N}_{\text {tot }}$ released from $\mathrm{BC}_{300}^{550}$ in soil was lower $\left(10.6 \mathrm{mg} \mathrm{g}^{-1} \mathrm{~N}\right)$ than from $\mathrm{BC}_{550}\left(16.0 \mathrm{mg} \mathrm{g}^{-1} \mathrm{~N}\right)$ and $\mathrm{BC}_{850}\left(17.7 \mathrm{mg} \mathrm{g}^{-1} \mathrm{~N}\right)$. This result indicates that $\mathrm{N}$ release from $\mathrm{BC}_{300}$ should be (i) lower in the soil than in water extract or (ii) $\mathrm{BC}_{300}$ not only released $\mathrm{N}$ into the soil, but it also adsorbed it from there. Experiment in aqueous environment by Gai et al. (2014) showed that biochar produced at $400 \ldots 500^{\circ} \mathrm{C}$ temperature adsorbed $\mathrm{NH}_{4}-\mathrm{N}$ and released $\mathrm{NO}_{3}-\mathrm{N}$, but it is not clear if similar process takes place also in the soil. The capability of biochar to adsorb $\mathrm{NH}_{4}-\mathrm{N}$ depends on the amount of negatively charged functional groups that is reduced with higher pyrolysis temperatures (Li et al., 2013; Gai et al., 2014). Among the biochars used in the current experiment, the amount of negatively charged functional groups was the greatest on the surface of the biochar produced at the lowest temperature (Escuer-Gatius et al., 2020) indicating that $\mathrm{BC}_{300}$ has prerequisite for $\mathrm{NH}_{4}-\mathrm{N}$ adsorption. Release and adsorption of $\mathrm{N}$ in the soil by hay biochar produced at low temperature needs precise study in the future.

Biochar impact on $\mathrm{N}, \mathrm{P}, \mathrm{K}, \mathrm{Ca}$ and $\mathrm{Mg}$ uptake by perennial ryegrass. The biochar increased plant $\mathrm{N}$, $\mathrm{P}$ and $\mathrm{K}$ uptake (NUP ${ }_{\text {tot }}$ ) and had no effect on $\mathrm{Ca}$ and $\mathrm{Mg}$ uptake (Table 3). The relative importance of biochar (indicated by $\%$ of $R^{2}$ ) was the highest for $\mathrm{K}$ uptake (Table 4).

The increased nutrient uptake was related to the increased aboveground biomass yield $(p<0.01)$ and higher concentration of $\mathrm{P}(p<0.01)$ and $\mathrm{K}(p<0.01)$

Table 3. Cumulative nutrient uptake by perennial ryegrass (above + below ground biomass) $\left(\mathrm{g} \mathrm{m}^{-2}\right)$

\begin{tabular}{ccccc}
\hline \multirow{2}{*}{ Treatment } & \multicolumn{4}{c}{ Uptake } \\
\cline { 2 - 5 } & $\mathrm{N}$ & $\mathrm{P}$ & $\mathrm{K}$ & $\mathrm{Ca}$ \\
\hline Control & $9.60 \mathrm{~B} \pm 0.24$ & $1.30 \mathrm{C} \pm 0.02$ & $15.30 \mathrm{~B} \pm 0.18$ & $4.40 \mathrm{AB} \pm 0.04$ \\
$\mathrm{BC}_{300}$ & $11.63 \mathrm{~A} \pm 0.60$ & $1.53 \mathrm{BC} \pm 0.01$ & $20.49 \mathrm{~A} \pm 0.41$ & $4.89 \mathrm{~A} \pm 0.09$ \\
$\mathrm{BC}_{550}$ & $11.45 \mathrm{~A} \pm 0.17$ & $1.75 \mathrm{~A} \pm 0.06$ & $20.40 \mathrm{~A} \pm 0.20$ & $4.13 \mathrm{AB} \pm 0.32$ \\
$\mathrm{BC}_{850}$ & $12.06 \mathrm{~A} \pm 0.29$ & $1.66 \mathrm{AB} \pm 0.07$ & $20.9 \mathrm{~A} \pm 0.56$ & $3.93 \mathrm{~B} \pm 0.25$ \\
\hline
\end{tabular}

Note. The index indicates the temperature, at which the biochar $(\mathrm{BC})$ was produced $\left(300^{\circ} \mathrm{C}, 550^{\circ} \mathrm{C}\right.$ or $\left.850^{\circ} \mathrm{C}\right)$; the values are presented as mean \pm standard error $(n=4)$; results marked with different capital letters are statistically different among treatments.

Table 4. Results of one-way ANOVA testing the effects of amendment of biochar on nutrient uptake

\begin{tabular}{|c|c|c|c|c|c|c|c|c|c|c|}
\hline & \multicolumn{2}{|c|}{$\mathrm{N}$} & \multicolumn{2}{|c|}{$\mathrm{P}$} & \multicolumn{2}{|c|}{$\mathrm{K}$} & \multicolumn{2}{|c|}{$\mathrm{Ca}$} & \multicolumn{2}{|c|}{$\mathrm{Mg}$} \\
\hline & $\%$ of $R^{2}$ & $P$ & $\%$ of $R^{2}$ & $P$ & $\%$ of $R^{2}$ & $P$ & $\%$ of $R^{2}$ & $P$ & $\%$ of $R^{2}$ & $P$ \\
\hline \multirow{2}{*}{ Biochar } & 65.5 & 0.01 & 58.8 & 0.01 & 92.0 & 0.01 & 0.7 & 0.75 & 13.5 & 0.16 \\
\hline & $R^{2}=0.63$ & 0.01 & $R^{2}=0.56$ & 0.01 & $R^{2}=0.91$ & 0.01 & $R^{2}=0.06$ & 0.75 & $R^{2}=0.07$ & 0.16 \\
\hline
\end{tabular}

Note. Relative importance of factor is indicated by $\%$ of $R^{2}(\mathrm{n}=16)$.

in shoots and roots and $\mathrm{N}$ only in shoots $(p<0.01)$. The methodology used in the experiment did not allow us to determine precisely how much of the nutrients assimilated by plants originated from biochar. It was only possible to estimate indirectly based on the nutrient amount released from biochar, the nutrient uptake and the change of the nutrient amount in the soil during the experiment. The hay biochar used in the current study was rich in $\mathrm{K}$, and during the experiment $\mathrm{K}$ was released to the soil in much higher quantities $\left(32.2 \mathrm{~g} \mathrm{~m}^{-2}\right)$ than it 
was assimilated by plants $\left(20.6 \mathrm{~g} \mathrm{~m}^{-2}\right)$. At the end of the experiment, soil $\mathrm{K}_{\text {tot }}$ and $\mathrm{K}_{\mathrm{AL}}$ in the biochar treatments were higher $(p<0.01)$ than in the control (Tables 5 and 6) and also when compared with the concentration at the beginning experiment. This result suggests that increase of $\mathrm{K}$ uptake was mainly due to $\mathrm{K}$, which was released from the biochar. The exception was $\mathrm{BC}_{300}$ treatment, where $\mathrm{K}_{\text {tot }}$ concentration in the soil at the end of the experiment did not differ significantly from that of the control. A positive effect of biochar on soil and plant biomass $\mathrm{K}$ uptake has been noted in many studies (Gaskin et al., 2010; Kloss et al., 2014; Zemanová et al., 2017), but it is significant only when the concentration of $\mathrm{K}$ in biochar is high (Gaskin et al., 2010), as was the case with hay biochar in this experiment.

Table 5. Soil acidity $(\mathrm{pH})$, total (tot) nutrient concentration $\left(\mathrm{g} \mathrm{kg}^{-1} \mathrm{DM}\right)$ in the $0-10 \mathrm{~cm}$ soil layer at the end of the experiment

\begin{tabular}{ccccccc}
\hline $\begin{array}{c}\text { Biochar } \\
(\mathrm{BC})\end{array}$ & $\mathrm{pH}$ & $\mathrm{N}_{\text {tot }}$ & $\mathrm{P}_{\text {tot }}$ & $\mathrm{K}_{\text {tot }}$ & $\mathrm{Ca}_{\text {tot }}$ & $\mathrm{Mg}_{\text {tot }}$ \\
\hline Control & $5.1 \mathrm{~A} \pm 0.09$ & $0.641 \mathrm{~A} \pm 0.01$ & $0.23 \mathrm{~A} \pm 0.02$ & $0.71 \mathrm{~A} \pm 0.02$ & $0.77 \mathrm{~A} \pm 0.08$ & $1.64 \mathrm{~A} \pm 0.04$ \\
$\mathrm{BC}_{300}$ & $5.4 \mathrm{~B} \pm 0.07$ & $0.65 \mathrm{~A} \pm 0.01$ & $0.13 \mathrm{~B} \pm 0.01$ & $0.85 \mathrm{~A} \pm 0.05$ & $0.80 \mathrm{~A} \pm 0.04$ & $1.72 \mathrm{~A} \pm 0.05$ \\
$\mathrm{BC}_{550}$ & $5.8 \mathrm{C} \pm 0.09$ & $0.73 \mathrm{~A} \pm 0.03$ & $0.13 \mathrm{~B} \pm 0.03$ & $1.18 \mathrm{~B} \pm 0.03$ & $0.88 \mathrm{~A} \pm 0.05$ & $1.72 \mathrm{~A} \pm 0.03$ \\
$\mathrm{BC}_{850}$ & $5.8 \mathrm{C} \pm 0.03$ & $0.67 \mathrm{~A} \pm 0.03$ & $0.14 \mathrm{~B} \pm 0.02$ & $1.24 \mathrm{~B} \pm 0.06$ & $0.78 \mathrm{~A} \pm 0.03$ & $1.65 \mathrm{~A} \pm 0.04$ \\
\hline
\end{tabular}

Note. The index indicates the temperature $\left(300^{\circ} \mathrm{C}, 550^{\circ} \mathrm{C}\right.$ or $\left.850^{\circ} \mathrm{C}\right)$, at which the biochar was produced; the values are presented as mean \pm standard error $(n=4)$; the results marked with different capital letters are statistically different at the 0.05 level; prior to the analysis, the biochar granules were removed from soil by sieving.

Table 6. Soil plant-available nutrient concentration $\left(\mathrm{mg} \mathrm{kg}^{-1} \mathrm{DM}\right)$ in the $0-10 \mathrm{~cm}$ soil layer at the end of the experiment

\begin{tabular}{ccccc}
\hline Biochar $(\mathrm{BC})$ & $\mathrm{P}_{\mathrm{AL}}$ & $\mathrm{K}_{\mathrm{AL}}$ & $\mathrm{Ca}_{\mathrm{AL}}$ & $\mathrm{Mg}_{\mathrm{AL}}$ \\
\hline Control & $12.3 \mathrm{~A} \pm 1.75$ & $3.5 \mathrm{D} \pm 2.3$ & $565.3 \mathrm{~A} \pm 27.5$ & $116.2 \mathrm{~A} \pm 4.5$ \\
$\mathrm{BC}_{300}$ & $8.9 \mathrm{~A} \pm 1.63$ & $125.9 \mathrm{C} \pm 5.7$ & $551.6 \mathrm{~A} \pm 9.3$ & $133.5 \mathrm{~A} \pm 3.7$ \\
$\mathrm{BC}_{550}$ & $14.2 \mathrm{~A} \pm 1.45$ & $277.1 \mathrm{~A} \pm 9.4$ & $729.7 \mathrm{~A} \pm 41.0$ & $137.9 \mathrm{~A} \pm 5.5$ \\
$\mathrm{BC}_{850}$ & $16.8 \mathrm{~A} \pm 2.62$ & $243.6 \mathrm{~B} \pm 8.4$ & $742.6 \mathrm{~A} \pm 113.1$ & $128.8 \mathrm{~A} \pm 8.8$ \\
\hline
\end{tabular}

Note. The index indicates the temperature $\left(300^{\circ} \mathrm{C}, 550^{\circ} \mathrm{C}\right.$ or $\left.850^{\circ} \mathrm{C}\right)$, at which the biochar was produced; the values are presented as mean \pm standard error $(n=4)$; the results marked with different capital letters are statistically different at the 0.05 level; prior to the analysis, the biochar pellets granules were removed from soil by sieving.

The P uptake $\left(1.7 \mathrm{~g} \mathrm{~m}^{-2} \mathrm{P}\right)$ was approximately 1.5 times higher compared with the amount of $\mathrm{P}\left(1.1 \mathrm{~g} \mathrm{~m}^{-2}\right.$ $\mathrm{P})$ released into the soil from biochar. The concentration of $\mathrm{P}_{\text {tot }}$ in the soil at the end of the experiment was significantly lower compared with that at the beginning of the experiment, suggesting that major part of $\mathrm{P}$ assimilated by plants during experiment originated from soil. The impact of biochar on P uptake was associated with the reduction of soil acidity, which increased $\mathrm{P}$ mobility in the soil. This was indicated by the positive relationship between $\mathrm{P}$ uptake and soil acidity (Table 7).

Table 7. Pearson correlation coefficients of the linear relationship between nutrient uptake and soil acidity $(\mathrm{pH})$ and total nutrient and plant-available nutrient concentration at the end of the experiment

\begin{tabular}{cccccc}
\hline \multirow{2}{*}{ Characteristic } & \multicolumn{7}{c}{ Uptake } \\
\cline { 2 - 6 } & $\mathrm{N}$ & $\mathrm{P}$ & $\mathrm{K}$ & $\mathrm{Ca}$ & $\mathrm{Mg}$ \\
\hline $\mathrm{pH}$ & $\mathbf{0 . 7 4}$ & $\mathbf{0 . 7 8}$ & $\mathbf{0 . 7 6}$ & $\mathbf{- 0 . 5 0}$ & 0.21 \\
$\mathrm{~N}_{\text {tot }}$ & 0.04 & 0.30 & 0.21 & $\mathbf{- 0 . 5 2}$ & 0.04 \\
$\mathrm{P}_{\text {tot }}$ & $\mathbf{- 0 . 7 2}$ & $\mathbf{- 0 . 5 2}$ & $\mathbf{- 0 . 7 2}$ & 0.27 & -0.00 \\
$\mathrm{~K}_{\text {tot }}$ & $\mathbf{0 . 6 3}$ & $\mathbf{0 . 8 0}$ & $\mathbf{0 . 6 8}$ & -0.43 & 0.28 \\
$\mathrm{Ca}_{\text {tot }}$ & 0.12 & 0.30 & 0.22 & -0.11 & 0.29 \\
$\mathrm{Mg}_{\text {tot }}$ & 0.04 & 0.15 & 0.10 & 0.25 & 0.52 \\
$\mathrm{P}_{\mathrm{AL}}$ & 0.10 & 0.32 & -0.06 & 0.07 & 0.14 \\
$\mathrm{~K}_{\mathrm{AL}}$ & $\mathbf{0 . 6 8}$ & $\mathbf{0 . 8 5}$ & 0.77 & -0.50 & 0.25 \\
$\mathrm{Ca}_{\mathrm{AL}}$ & 0.47 & $\mathbf{0 . 6 5}$ & 0.40 & -0.28 & 0.19 \\
$\mathrm{Mg}_{\mathrm{AL}}$ & $\mathbf{0 . 6 5}$ & $\mathbf{0 . 6 1}$ & $\mathbf{0 . 6 0}$ & -0.02 & 0.37 \\
$\mathrm{Ca}_{\text {tot }}: \mathrm{K}_{\text {tot }}$ & $\mathbf{- 0 . 8 1}$ & $\mathbf{- 0 . 7 9}$ & $\mathbf{- 0 . 9 4}$ & 0.19 & -0.33 \\
$\mathrm{Mg}_{\text {to: }}: \mathrm{K}_{\text {tot }}$ & 0.18 & 0.42 & 0.12 & -0.37 & -0.03 \\
\hline
\end{tabular}

Note. Correlations marked in bold are significant at the 0.05 level $(\mathrm{n}=3)$.
This result is in accordance with the previous studies (Kloss et al., 2014; Jeffery et al., 2017), which have also shown that biochar incorporation into acidic soil reduces its acidity resulting in increased $P$ availability.

Nitrogen uptake in biochar treatments was significantly higher than in the control. The biggest difference was seen during the $1^{\text {st }}$ cut when plants in biochar treatments assimilated on average $42 \%$ more $\mathrm{N}(p<0.001)$ than from the control. During the $2^{\text {nd }}$ cut the difference was $8 \%(p<0.05)$. The $\mathrm{N}$ concentration of biomass harvested from biochar and control treatment differed only during the $2^{\text {nd }}$ cut $(p<0.001)$. The amount of $\mathrm{N}$ released from biochar in every treatment was different (Table 8), but there was no significant relationship between released $\mathrm{N}$ amount and $\mathrm{N}$ uptake, which shows that direct effect of biochar as $\mathrm{N}$ source on the plants was low.

Nitrogen uptake significantly correlated with $\mathrm{P}_{\text {to }}$ and $\mathrm{K}_{\mathrm{AL}}$ concentration in the soil at the end of experiment suggesting that plants assimilated more $\mathrm{N}$ in biochar treatments mainly due to the higher amount of $\mathrm{P}_{\mathrm{AL}}$ and $\mathrm{K}_{\mathrm{AL}}$ in the soil (Table 7). Also was found that biochar increased substantially the $\mathrm{N}$ loss from soil (Table 8 ), which was partly due to increased $(p<0.01)$ nitrous oxide $\left(\mathrm{N}_{2} \mathrm{O}\right)$ emission from soil (Escuer-Gatius et al., 2020). This result suggests that part of $\mathrm{N}$ released from biochar could have emitted from the soil during experiment, and this could be one of the reasons why the impact of $\mathrm{N}$, released from biochar, on plants $\mathrm{N}$ uptake was low.

So far the research has shown that biochar increases $\mathrm{Ca}$ and $\mathrm{Mg}$ uptake (Laghari et al., 2016), but it can also reduce $\mathrm{Ca}$ uptake if it is adsorbed onto $\mathrm{Fe}$ and $\mathrm{Al}$ oxides (Smider, Singht, 2014). The reason for the neutral impact of biochar on $\mathrm{Ca}$ and $\mathrm{Mg}$ uptake in the present research could be due to its very high $\mathrm{K}$ concentration, 
Table 8. The amount of nitrogen $(\mathrm{N})$ in the soil at the beginning and at the end of the experiment, amount of $\mathrm{N}$ released from biochar $(\mathrm{BC})$ during experiment, $\mathrm{N}$ uptake and $\mathrm{N}$ loss $\left(\mathrm{g} \mathrm{pot}^{-1}\right)$

\begin{tabular}{cccccc}
\hline Treatment & $\begin{array}{c}\text { N amount } \\
\text { in soil at the } \\
\text { beginning } \\
\text { of experiment }\end{array}$ & $\begin{array}{c}\text { N amount released } \\
\text { from biochar } \\
\text { during experiment }\end{array}$ & $\begin{array}{c}\mathrm{N}_{\text {tot }} \text { amount in soil } \\
\text { at the end } \\
\text { of experiment }\end{array}$ & $\begin{array}{c}\mathrm{N} \\
\text { uptake }\end{array}$ & $\begin{array}{c}\mathrm{N} \\
\text { loss }\end{array}$ \\
\hline Control & 2.24 & - & $2.01 \pm 0.05$ & $0.09 \pm 0.002$ & $0.14 \pm 0.05$ \\
$\mathrm{BC}_{300}$ & 2.24 & $0.09 \pm 0.06$ & $1.94 \pm 0.14$ & $0.12 \pm 0.006$ & $0.27 \pm 0.13$ \\
$\mathrm{BC}_{550}$ & 2.24 & $0.14 \pm 0.04$ & $1.96 \pm 0.04$ & $0.11 \pm 0.0002$ & $0.31 \pm 0.04$ \\
$\mathrm{BC}_{850}$ & 2.24 & $0.15 \pm 0.03$ & $2.08 \pm 0.05$ & $0.12 \pm 0.003$ & $0.19 \pm 0.05$ \\
\hline
\end{tabular}

which could have caused the unbalanced ratio of $\mathrm{K}$ and $\mathrm{Ca}$ as well as $\mathrm{K}$ and $\mathrm{Mg}$ in the soil. At the beginning of the experiment, the soil $\mathrm{Ca}_{\mathrm{AL}}: \mathrm{K}_{\mathrm{AL}}$ was $7: 1$, but by the end of experiment it was decreased to $3: 1$, because by biochar application 2-3 times more $\mathrm{K}$ relative to $\mathrm{Ca}$ was taken into the soil. At the start of the experiment, the ratio of $\mathrm{Mg}_{\mathrm{AL}}: \mathrm{K}_{\mathrm{AL}}$ in the soil was $2: 1$, but it decreased to $1: 1.4$ by the end of the experiment. It has been previously shown also by Zemanová et al. (2017) that the application of biochar into the soil changes the ratio of $\mathrm{Ca}: \mathrm{K}$ and
$\mathrm{Mg}: \mathrm{K}$, due to which the plant availability of $\mathrm{Ca}$ and $\mathrm{Mg}$ decreased because of antagonistic interaction mechanism between $\mathrm{Ca}, \mathrm{Mg}$ and $\mathrm{K}$. This shows that one should be careful when using biochar with high $\mathrm{K}$ concentration in the soil with low concentration of $\mathrm{Ca}$ and $\mathrm{Mg}$, where it could decrease the uptake of these elements by the plants.

Biochar impact on nutrient uptake did not depend significantly on temperature, at which it was produced (Table 9).

Table 9. Results of analysis of one-way ANOVA testing the effects of pyrolysis temperature of biochar on nutrient uptake by perennial ryegrass

\begin{tabular}{ccccccccccc}
\hline \multirow{2}{*}{ Uptake } & \multicolumn{2}{c}{$\mathrm{N}$} & \multicolumn{2}{c}{$\mathrm{P}$} & $\mathrm{K}$ & \multicolumn{2}{c}{$\mathrm{Ca}$} & \multicolumn{2}{c}{$\mathrm{Mg}$} \\
\cline { 2 - 13 } & $\%$ of $R^{2}$ & $P$ & $\%$ of $R^{2}$ & $P$ & $\%$ of $R^{2}$ & $P$ & $\%$ of $R^{2}$ & $P$ & $\%$ of $R^{2}$ & $P$ \\
\hline Pyrolysis & 12.4 & 0.55 & 49.7 & 0.045 & 8.76 & 0.66 & 48.71 & 0.051 & 14.1 & 0.51 \\
\cline { 2 - 12 } temperature & $R^{2}=0.12$ & 0.55 & $R^{2}=0.50$ & 0.045 & $R^{2}=0.09$ & 0.66 & $R^{2}=0.49$ & 0.049 & $R^{2}=0.14$ & 0.51 \\
\hline
\end{tabular}

Note. The relative importance of factor is indicated by $\%$ of $R^{2}(\mathrm{n}=12)$.

The exception was $\mathrm{P}$ uptake, which was the highest in $\mathrm{BC}_{550}$ and lowest in $\mathrm{BC}_{300}$ treatment (Table 3). This result shows that the changes occurring in biochar with the increasing pyrolysis temperature such as increased nutrient concentration and increase in acid neutralization capacity do not have a major influence on the impact the biochar has on nutrient uptake. We noted at the end of the experiment that in $\mathrm{BC}_{300}$ treatment the pellets granules were so strongly colonized by plant roots that they had to be removed with force. This suggests that in the $\mathrm{BC}_{300}$ treatment the plants assimilated nutrients also directly from the surface of the biochar, which could have partly compensated for the lower effect of biochar on soil acidity and on $\mathrm{P}$ availability in the soil. In contrast, plant roots did not attach to the $\mathrm{BC}_{550}$ and $\mathrm{BC}_{850}$ pellets because of their very high acidity.

Biomass yield of perennial ryegrass. The biochar increased the $1^{\text {st }}$ cut yield of perennial ryegrass on average by $40 \%(p<0.01)$ compared to the control treatment (Table 10), but it did not have a significant effect on the $2^{\text {nd }}$ cut yield, which is consistent with the conclusion by Rajkovich et al. (2012), which suggests that graminaceous biochar improves the plant growth over a short period. The effect of biochar on the yield showed no significant relationship with the pyrolysis temperature.

Table 10. Perennial ryegrass aboveground biomass yield $\left(\mathrm{g} \mathrm{DM} \mathrm{m}^{-2}\right)$

\begin{tabular}{ccc}
\hline Treatment & $1^{\text {st }}$ cut & $2^{\text {nd }}$ cut \\
\hline Control & $194.7 \mathrm{~A} \pm 9.1$ & $189.5 \mathrm{~A} \pm 1.0$ \\
$\mathrm{BC}_{300}$ & $271.1 \mathrm{~B} \pm 9.0$ & $189.5 \mathrm{~A} \pm 7.4$ \\
$\mathrm{BC}_{550}$ & $268.4 \mathrm{~B} \pm 13.9$ & $184.2 \mathrm{~A} \pm 6.8$ \\
$\mathrm{BC}_{850}$ & $276.3 \mathrm{~B} \pm 13.8$ & $197.4 \mathrm{~A} \pm 9.0$ \\
\hline
\end{tabular}

Results of our experiment demonstrated that yield increase ( $40 \%$ on average) in biochar treatments was mainly due to the reduction of soil acidity, which increased $\mathrm{P}$ availability to plants. Moreover, the large amount of $\mathrm{K}$ that was released from biochar could have had a positive influence on the yield, as the K concentration of the soil itself was low. This result supports the findings of previous research, according to which biochar acts as a liming agent and short-term fertilizer in low-nutrient acidic soils (Kloss et al., 2014; Jeffrey et al., 2017).

\section{Conclusions}

1. The permanent grassland hay dominated by reed canary grass is a suitable raw material for biochar (BC) production. This biochar is a fast-acting potassium (K) rich liming agent, which also contains remarkable amount of nitrogen $(\mathrm{N})$. The addition of this biochar into acidic soil reduced the soil acidity and significantly increased plant $\mathrm{N}, \mathrm{P}$ and $\mathrm{K}$ uptake, which had positive impact on the biomass yield of perennial ryegrass.

2. The increase of pyrolysis temperature changed biochar properties like neutralization capacity, acidity $(\mathrm{pH})$, nutrient concentration and the release of nutrients from biochar, but these changes did not have significant impact on the effect the biochar had on plant nutrition and yield as the effect of all three biochars on them was similar. The only exception was phosphorus (P) uptake, which was the highest when the biochar was produced at $550^{\circ} \mathrm{C}$ temperature.

3. The results of the present research suggested that the biochar produced from permanent grassland hay at $300^{\circ} \mathrm{C}$ temperature could concurrently release and adsorb $\mathrm{N}$ in the soil. This hypothesis needs to be proved or disapproved in future studies. 


\section{Acknowledgements}

The research was funded by the Estonian Agricultural Registers and Information Board (ARIB) program "Support for development of new products, practices, processes and technologies". We thank the research contractor Taivo Roomann from Leedi farm in Rapla County and the project coordinator Tommy Bienet. We thank Alex Boon of Soil Science Editing for editing a draft of this manuscript.

Received 27102019

Accepted 02042020

\section{References}

1. AOAC. 1990. Official methods of analysis of the AOAC (15 ${ }^{\text {th }}$ ed.).

2. Baiamonte G., De Pasquale C., Marsala V., Cimò G., Alonzo G., Crescimanno G., Conte P. 2015. Structure alteration of a sandy-clay soil by biochar amendments. Journal of Soils Sediments, 15 (4): 816-824. https://doi.org/10.1007/s11368-014-0960-y

3. Basso A. S., Miguez F. E., Laird D. A., Horton R., Westgate M. 2013. Assessing potential of biochar for increasing water-holding capacity of sandy soils. Global Change Biology Bioenergy, 5 (2): 132-143. https://doi.org/10.1111/gcbb.12026

4. Brunauer S., Emmett P. H., Teller E. 1938. Adsorption of gases in multimolecular layers. Journal of the American Chemical Society, 60: 309-319. https://doi.org/10.1021/ja01269a023

5. Buchkina N. P., Hüppi R., Leifeld J. 2019. Biochar and short-term $\mathrm{N}_{2} \mathrm{O}$ and $\mathrm{CO}_{2}$ emission from plan residue-amended soil with different fertilisation history. Zemdirbyste-Agriculture, 106 (2): 99-106. https://doi.org/10.13080/z-a.2019.106.013

6. Cayuela M. L., van Zwieten L., Singh B. P., Jeffery S., Roig A., Sánchez-Monedero M. A. 2014. Biochar's role in mitigating soil nitrous oxide emissions: a review and meta-analysis. Agriculture Ecosystem and Environment, 191: 5-16. https://doi.org/10.1016/j.agee.2013.10.009

7. Ding Y., Liu Y. G., Liu S. B., Li Z. W., Tan X. F., Huang X. X. 2016. Biochar to improve soil fertility: a review. Agronomy for Sustainable Development, 36: 36. https://doi.org/10.1007/s13593-016-0372-z

8. Egner H., Riehm H., Domingo W. R. 1960. Investigations of the chemical soil analysis as a basis for the evaluation of nutrient status in soil. II. Chemical extraction methods of phosphorus and potassium determination. Kungliga Lantbrukshügskolans Annaler, 26: 199-215 (in German).

9. Enders A., Hanley K., Whitman T., Joseph S., Lehmann J. 2012. Characterization of biochars to evaluate recalcitrance and agronomic performance. Bioresource Technology, 114: 644-653. https://doi.org/10.1016/j.biortech.2012.03.022

10. Escuer-Gatius J., Shanskiy M., Soosaar K., Astover A., Raave H. 2020. High-temperature hay biochar application into soil increases $\mathrm{N}_{2} \mathrm{O}$ fluxes. Agronomy, 10 (1): 109. https://doi.org/10.3390/agronomy10010109

11. Feng Z., Zhu L. 2017. Impact of biochar on soil $\mathrm{N}_{2} \mathrm{O}$ emissions under different biochar-carbon/fertilizernitrogen ratios at a constant moisture condition on a silt loam soil. Science of the Total Environment, 584-585: 776-782. https://doi.org/10.1016/j.scitotenv.2017.01.115

12. Gai X., Wang H., Liu J., Zhai L., Liu S., Ren T., Liu H. 2014. Effects of feedstock and pyrolysis temperature on biochar adsorption of ammonium and nitrate. PLoS ONE, 9 (12): e113888. https://doi.org/10.1371/journal.pone.0113888

13. Gaskin J. W., Speir R. A., Harris K., Das K. C., Lee R. D., Morris L. A., Fisher D. S. 2010. Effect of peanut hull and pine chip biochar on soil nutrients corn nutrient status and yield. Agronomy Journal, 102 (2): 623-633. https://doi.org/10.2134/agronj2009.0083
14. Heinsoo K., Melts I., Sammul M., Holm B. 2010. The potential of Estonian semi-natural grasslands for bioenergy production. Agriculture Ecosystem and Environment, 137: 86-92.

https://doi.org/10.1016/j.agee.2010.01.003

15. Ippolito J. A., Spokas K. A., Novak J. M., Lentz R. D., Cantrell K. B. 2015. Biochar elemental composition and factors influencing nutrient retention. Lehmann J., Joseph S. (eds). Biochar for environmental management. Science and technology, chapter 7, p. 137-161.

16. Jeffery S., Abalos D., Prodana M., Bastos A. C., Groenigen J. W., Bruce A., Hungate B. A., Verheijen F. 2017. Biochar boosts tropical but not temperate crop yields. Environmental Research Letters, 12: 5. https://doi.org/10.1088/1748-9326/aa67bd

17. Kloss S., Zehetner F., Dellantonio A., Hamid R., Ottner F., Liedtke V., Schwanninger M., Gerzabek M. H., Soja G. 2012. Characterization of slow pyrolysis biochars: effects of feedstocks and pyrolysis temperature on biochar properties. Journal of Environmental Quality, 41 (4): 990 1000. https://doi.org/10.2134/jeq2011.0070

18. Kloss S., Zehetner F., Wimmer B., Buecker J., Rempt F., Soja G. 2014. Biochar application to temperate soils: effects on soil fertility and crop growth under greenhouse conditions. Journal of Plant Nutrition and Soil Science, 177: 3-15. https://doi.org/10.1002/jpln.201200282

19. Kukk L., Astover A., Roostalu H., Rossner H., Tamm I. 2010. The dependence of reed canary grass (Phalaris arundinacea L.) energy efficiency and profitability on nitrogen fertilization and transportation distance. Agronomy Research, 8: 123-133.

20. Laghari M., Naidu R., Xiao B., Hu Z., Mirjat M. S., Hu M. 2016. Recent developments in biochar as an effective tool for agricultural soil management: a review. Journal of the Science of Food and Agriculture, 96 (15): 4840-4849. https://doi.org/10.1002/jsfa.7753

21. Lastoskie C., Gubbins K. E., Quirke N. 1993. Pore size distribution analysis of microporous carbons: a density functional theory approach. The Journal of Physical Chemistry, 97: 4786-4796.

https://doi.org/10.1021/j100120a035

22. Lehmann J., Joseph S. 2015. Biochar for environmental management: an introduction. Lehmann J., Joseph S. (eds). Biochar for environmental management. Science and technology, chapter 1, p. 1-12.

23. Li X. M., Shen Q. R., Zhang D. Q., Mei X. L., Ran W., Xu Y. C., Yu G. H. 2013. Functional groups determine biochar properties (pH and EC) as studied by two dimensional 13C NMR correlation spectroscopy. PLoS ONE, 8 (6): e65949. https://doi.org/10.1371/journal.pone.0065949

24. Ma N. L., Zhang Y., Zhang L., Yang C., Yu G., Yin G., Doane T. A., Wu Z., Zhu P., Ma X. 2016. Biochar improves soil aggregate stability and water availability in a mollisol after three years of field application. PLoS ONE, 11 (5): e0154091. https://doi.org/10.1371/journal.pone.0154091

25. Mimmo T., Panzacchi P., Baratier M., Davies C. A., Tonon G. 2014. Effect of pyrolysis temperature on miscanthus (Miscanthus $\times$ giganteus) biochar physical, chemical and functional properties. Biomass and Bioenergy, 62: 149-157. https://doi.org/10.1016/j.biombioe.2014.01.004

26. Mukherjee A., Zimmerman A. R. 2013. Organic carbon and nutrient release from a range of laboratoryproduced biochars and biochar-soil mixtures. Geoderma, 193-194: 122-130. https://doi.org/10.1016/j.geoderma.2012.10.002

27. Naeem M. A., Khalid M., Arshad M., Ahmad R. 2014. Yield and nutrient composition of biochar produced from different feedstocks at varying pyrolytic temperatures. Pakistan Journal of Agricultural Sciences, 51 (1): 75-82.

28. Nelissen V., Ruysschaert G., Müller-Stöver D., Bodé S., Cook J., Ronsse F., Shackley S., Boeckx P., HauggaardNielsen H. 2014. Short-term effect of feedstock and pyrolysis temperature on biochar characteristics. Soil and crop response in temperate soils. Agronomy, 4 (1): 52-73. https://doi.org/10.3390/agronomy4010052 
29. Nelissen V., Ruysschaert G., Manka'Abusi D., D’Hose T., De Beuf K., Al-Barri B., Cornelis W., Boeckx P. 2015. Impact of a woody biochar on properties of a sandy loam soil and spring barley during a two-year field experiment. European Journal of Agronomy, 62: 65-78. https://doi.org/10.1016/j.eja.2014.09.006

30. Novak J. M., Lima I., Xing B., Gaskin J. W., Steiner C., Das K. C., Ahmedna M., Rehrah D., Watts D. W., Busscher W. J., Schomberg H. 2009. Characterization of designer biochar produced at different temperatures and their effects on a loamy sand. Annals of Environmental Science, 3: 195-206.

31. Rajkovich S., Enders A., Hanley K., Hyland C., Zimmerman A. R., Lehmann J. 2012. Corn growth and nitrogen nutrition after additions of biochars with varying properties to a temperate soil. Biology and Fertility of Soils, 48: 271-284.

https://doi.org/10.1007/s00374-011-0624-7

32. Ruzicka J., Hansen E. H. 1988. Flow injection analysis ( $2^{\text {nd }}$ ed.). Wiley, $528 \mathrm{p}$. https://doi.org/10.1016/S0003-2670(00)80313-X

33. Smider B., Singh B. 2014. Agronomic performance of a high ash biochar in two contrasting soils. Agriculture Ecosystems and Environment, 191: 99-107. https://doi.org/10.1016/j.agee.2014.01.024

34. Sohi S. P. 2012. Carbon storage with benefits. Science, 338 (6110): 1034-1035.

https://doi.org/10.1126/science.1225987
35. Van de Voorde T. F. J., van Noppen F., Nachenius R. W., Prins W., Mommer L., VanGroenigen J. W., Bezemer T. M. 2014. Biochars produced from individual grassland species differ in their effect on plant growth. Basic and Applied Ecology, 15 (1): 18-25. https://doi.org/10.1016/j.baae.2013.12.005

36. Wang T., Arbestain M. C., Hedley M., Bishop P. 2012. Chemical and bioassay characterisation of nitrogen availability in biochar produced from dairy manure and biosolids. Organic Geochemistry, 51: 45-54.

https://doi.org/10.1016/j.orggeochem.2012.07.009

37. Wang S., Gao B., Zimmerman A. R., Li Y., Ma L., Harris W. G., Migliaccio K. W. 2015. Physicochemical and sorptive properties of biochars derived from woody and herbaceous biomass. Chemosphere, 134: 257-262. https://doi.org/10.1016/j.chemosphere.2015.04.062

38. WRB. 2014. World reference base for soil resources. World Soil Resources Reports No. 106. FAO, p. 187-189.

39. Zemanová V., Břendová K., Pavlíková D., Kubátová P., Tlustoš P. 2017. Effect of biochar application on the content of nutrients $(\mathrm{Ca}, \mathrm{Fe}, \mathrm{K}, \mathrm{Mg}, \mathrm{Na}, \mathrm{P})$ and amino acids in subsequently growing spinach and mustard. Plant, Soil and Environment, 7: 322-327. https://doi.org/10.17221/318/2017-PSE

40. Zheng H., Wang Z., Deng X., Zhao J., Luo Y., Novak J., Herbert S., Xing B. 2013. Characteristics and nutrient values of biochars produced from giant reed at different temperatures. Bioresource Technology, 130: 463-471. https://doi.org/10.1016/j.biortech.2012.12.044

\title{
Bioanglis, pagaminta iš daugiamečių pievų žolès, didina augalų N, P ir K įsisavinimą rūgščiame dirvožemyje
}

\author{
H. Raave ${ }^{1}$, J. Escuer-Gatius ${ }^{2}$, K. Kauer ${ }^{2}$, M. Shanskiy², T. Tõnutare², A. Astover ${ }^{2}$ \\ ${ }^{1}$ Estijos gyvybès mokslų universiteto Augalininkystès ir augalų biologijos katedra \\ ${ }^{2}$ Estijos gyvybès mokslų universiteto Dirvožemio mokslo katedra
}

\begin{abstract}
Santrauka
Estijoje yra daug derlingų ilgalaikių pievų, kuriose žolès pjaunamos kartą per metus, kad būtų išvengta antrinio miško medžiu augimo, tačiau nupjauta biomasè dèl mažos pašarinès vertes dažniausiai paliekama pūti. Vienas būdų šiems ištekliams suteikti vertę būtų jų panaudojimas bioanglies gamybai, siekiant padidinti anglies ir maisto medžiagų kiekị mažo derlingumo dirvožemiuose. Buvo tirta: (i) bioanglis, pagaminta iš ilgalaikių pievų žolių, naudojant tris $\left(300^{\circ} \mathrm{C}, 550^{\circ} \mathrm{C}\right.$ ir $\left.850^{\circ} \mathrm{C}\right)$ pirolizès temperatūras ir (ii) bioanglies ịtaka daugiametès svidrès (Lolium perenne L.) maisto medžiagų $\mathrm{N}, \mathrm{P}, \mathrm{K}, \mathrm{Ca}$ bei $\mathrm{Mg}$ ịsisavinimui ir biomasės derliui rūgščiame ( $\mathrm{pH} 4,2)$ dirvožemyje. Nustatyta, kad ilgalaikès pievos, kuriose vyravo nendrinis dryžutis (Phalaris arundinacea (L.), žolè yra tinkama žaliava bioanglies gamybai. Tokia bioanglis turi daug kalio (K), kaip greitai veikiančios kalkinès medžiagos, ir didelị kiekị azoto $(\mathrm{N})$. Ją ịterpus ị rūgštų dirvožemị, sumažèja jo rūgštumas ir reikšmingai padidèja daugiamečiu svidrių N, P ir K ịsisavinimas, o tai turi trumpalaikę teigiamą įtaką biomasès derliui. Pirolizès temperatūru didinimas keičia bioanglies savybes - neutralizacijos gebą, rūgštumą $(\mathrm{pH})$, maisto medžiagų koncentraciją ir jų atpalaidavimą, tačiau šie pokyčiai neturi reikšmingos ịtakos bioanglies poveikiui daugiamečị svidrių mitybai ir derliui. Išimtis buvo fosforo (P) įsisavinimas, kuris buvo didžiausias tręšiant bioanglimi, pagaminta $550^{\circ} \mathrm{C}$ temperatūroje.
\end{abstract}

Reikšminiai žodžiai: biomasès derlius, maisto medžiagų atpalaidavimas iš bioanglies, maisto medžiagu ìsisavinimas, bioanglies savybès, pirolizès temperatūra. 